International Human Rights Law Group. 1989. Chile: The Plebiscite and Beyond. Washington, DC: International Human Rights Law Group. February.

Latin American Studies Association. 1990. Electoral Democracy Under International Pressure. Pittsburgh, PA: LASA Secretariat. . 1984. The Electoral Process in Nicaragua: Domestic and International Influences. Austin, TX: LASA Secretariat. NDI Reports. 1990. Washington, D.C. National Democratic Institute for International Affairs, Summer.

Palley, Claire. 1979. The Rhodesian Elections. London: Catholic Institute for International Relations.

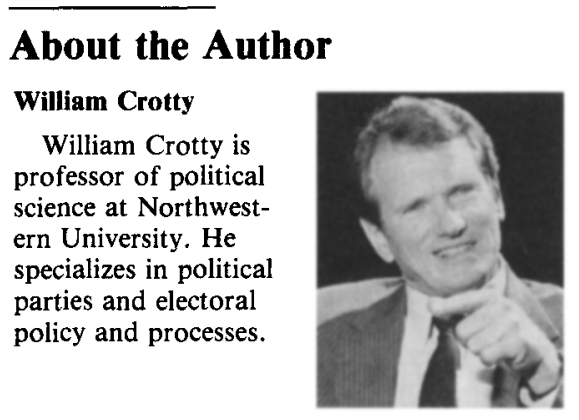

\title{
Why a Political Film Society?
}

\author{
Michael Haas, University of Hawaii at Manoa
}

Just as all life itself has political meaning, producers of commercial films operate within a political context. In most cases films have an implicit message, but in some cases the aim of a film is to make an important and explicit political statement.

My interest in political films dates from 1950, when the era of McCarthyism was reaching its peak. Courageous members of the film industry were being blacklisted, some for their political courage, others for frivolous reasons. The film community emerged from the shock of the blacklisting era rather quietly. Politically oriented films were rare in the 1950 s, compared to the consciousness raising of the 1940s, and the 1960s were tame compared to the 1970 s and 1980s.

The full story of the rise of political films has yet to be told, but it would certainly include The Birth of the Nation earlier in the century. One of the more contemporary landmarks was Warren Beatty's effort to portray the way the American Communist
Party was suppressed after World War I. After major film studios refused to produce his idea for such a film, he formed his own corporation to produce Reds, which combined a distinct political message with some "Don Juan" touches to make a film in the 1970s that would be at least marginally marketable.

The next major political film came in 1984. The Killing Fields emerged as possibly the most influential political film of all time. The horrors of the Pol Pot era in Cambodia had been reported in print, but the depth of the inhumanity was largely unappreciated until the film provided a portrayal unparalleled in the history of film. Most filmviewers are unaware that the producers cut a portion of the film that showed the joyous manner in which Cambodians greeted Vietnamese soldiers as liberators of their country from Pol Pot. Even so, later changes in U.S. policy toward Cambodia, which then covertly supported the Khmer Rouge, may be in some measure due to the success of The Killing Fields in raising the consciousness of millions of viewers.

Since political films entail considerable risk, they are still rare and usually uncelebrated. Accordingly, I decided to found the Political Film Society in 1986 as the first society in the world to recognize outstanding films with important political messages. The aim is to encourage more political films by rewarding those who know that political consciousness can be raised through film in a very special way.

Originally, the Political Film Society was formed as a project of the former Hawaii Political Studies Association (HPSA). At the first HPSA meeting a group of persons got together to review a proposed set of by-laws modelled closely on the constitution of the Academy of Motion Picture Arts and Sciences, which makes the annual academy awards. Since our aim was to reward content, not technical accomplishments, we established four major 
award categories. These categories are democracy, exposés, human rights, and peace.

A film that wins the democracy category for a particular year is viewed as the one that best raises the political consciousness of filmviewers on the superiority of democratic methods of governance over authoritarian rule. In 1988 The Milagro Beanfield War showed how a group of farmers combined forces to defeat developers from driving them out of business. In 1989 The Dead Poets Society showed how the power structure of a private school could be brought to bear on a teacher who was trying to enable students to think for themselves.

The expose is a film that brings deliberately suppressed facts to the attention of the public. $A$ Cry in the Dark won in 1988 as a story of an Australian woman who was accused of killing.her baby, when in fact a wild Australian dog was responsible; the press itself bore responsibility for a fiction that a dingo could not have dragged a baby to its death. The woman was released from jail as a result of the film. In 1989 Christine Keeler had a chance to tell her side of the Profumo affair in Scandal, though of course the judgment of whether she achieved any vindication is a matter of opinion.

The human rights category has been prominent as a political theme in recent years. Matewan, the story of the massacre of coal miners who wanted to belong to a union, won in 1987. Cry Freedom, the story of Steve Biko and his journalist friend in South Africa, topped the nominees in 1988. Mississippi Burning won in 1989. Although the aim was to commemorate the deaths of three civil rights workers, the subtext was that civil rights have progressed rather far in the United States since the perilous days of the 1960s.

Peace films are the most numerous of all the political films. Scenes from the war in Vietnam have been utilized to depict the evils of war. In 1987 Platoon demonstrated the dehumanization that results when soldiers fight an unjust war. In 1988 an armed forces radio announcer tried antiwar satire and then got booted out of the army in Good Morning,
Vietnam. In 1989 Casualties of War showed that a rape of one Vietnamese woman was a paradigm for the U.S. rape of all the people of Vietnam.

Because of the humble beginnings of the Political Film Society in the 50 th state as a project of HPSA, a fifth category has been added for the best political film about Hawaii. No film has even been nominated for the award despite the many political themes that could be utilized.

A sixth category is also unique for Hawaii, due to the existence of the annual Hawaii International Film Festival (HIFF) since the early 1980s. HIFF is organized by the East-West Center, an independent corporation located across the street from the University of Hawaii that provides scholarships for students from countries of the Asian and Pacific region. At first, HIFF films tended to have a conservative political message with the implicit theme that all countries undergo a process of cultural conflict produced by inexorable economic development, so the individual must either adjust or suffer but should not attempt political action in response. Since members of the Political Film Society were not happy about this covert message, a special award for the best political film of HIFF was established. The East-West Center, which gives awards of its own, has no control over what the Political Film Society believes to be HIFF's best political film. Although the Society does not allow documentaries for the five categoric awards, documentaries and feature films qualify equally for the award of the best HIFF political film.

The best political film of HIFF 1987 , as determined by the Political Film Society, was The Killing Fields (despite the abovementioned cuts). In 1988 a Vietnamese film, entitled Vietnam, won for a portrayal of how the Vietnamese government has coped with the environmental damage caused by defoliation during the U.S. war against Vietnam. In 1989 a film from Taiwan, $A$ City of Sadness, won as a statement of life in Taiwan as sovereignty was transferred in an authoritarian manner to the Republic of China in 1946.

The Political Film Society has an open membership, with members thus far from California, Hawaii, New England, and the Deep South. Any member can nominate any film in any category. A monthly newsletter informs members of nominated films throughout the year. If there are more than five nominees in a category within a calendar year, a vote is taken to reduce the list to five films; the final vote is then on the top five. If there is only one nominee for a category, there is a vote to see whether a majority agrees that the film should indeed receive an award.

So far this year nominees for the best political films include the following:

Democracy: Born on the Fourth of July

Exposé: Air America, Reversal of Fortune, Roger \& Me, Romero Human Rights: Driving Miss Daisy, Glory, Listen Up, Longtime Companion, Quigley Down Under, Romero

Peace: Dances with Wolves, Dreams

Members of the Political Film Society believe that a broader membership across the United States is warranted, now that the modus operandi of the organization has been established. The objective is to grow from an initial 100 members in 1986 to more than 10,000 members by the mid-1990s and ultimately to relocate its headquarters from Honolulu to Hollywood, where it can serve as a pressure group for serious political films.

The address of the Political Film Society is 2424 Maile Way, Suite 639, Honolulu, Hawaii 96822-2223. I am the coordinator. A $\$ 5.00$ membership fee is tax deductible; dues are paid to the University of Hawaii Foundation on behalf of the Society.

\section{About the Author}

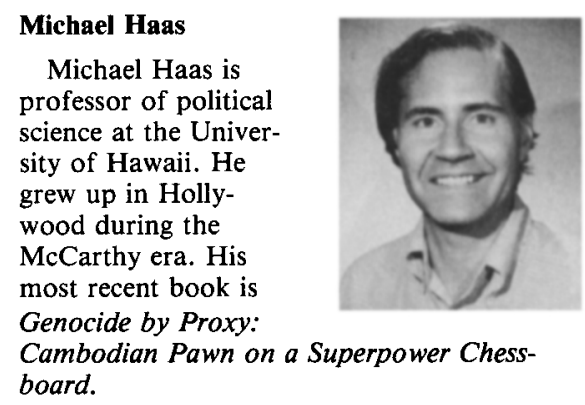

